\title{
Global generic competences with local ownership: a comparative study from the perspective of graduates in four world regions
}

\author{
Pablo Beneitone and Edurne Bartolomé
}

\begin{abstract}
The article addresses the issue of generic competences across different cultural contexts in the world. Using the Tuning projects data collected in Europe, Latin America, Africa and Russia, and focusing on graduates' perspective, the authors aim to classify and compare the list of generic competences throughout all geographic regions covered by Tuning, analyse the importance and achievement given to the generic competences throughout different contexts, and also contrast the latent constructs obtained from the exploratory factor analysis, in order to observe how competences are classified and clustered across regions. The article shows and explains the main differences observed and stresses the relevance of taking into account the cultural context and the traditions of education systems, in order to properly understand the importance of generic competences in different regions, and also how, even though the competences are equivalent, they may articulate distinctive dimensions in each region.

Keywords: global analysis; generic competences; context-comparative approach; graduates; consultation process; factor analysis.
\end{abstract}

\section{Introduction}

There is a high level of agreement that internationalisation is one of the major characteristics of Higher Education at present. This is explained in many different ways. Educational paradigms are changing and the search for international indicators is a constant development in many parts of the world. However, empirical studies of the nature and the scope of the work explained here are not so frequent despite the impact of previous studies such as Geert Hofstede's cultural dimensions theory ${ }^{1}$ which was at the core of a significant number of intercultural studies, giving insights to the reality and the importance of cultural perceptions. Hofstede describes the effects of a society's culture on the values of its members, and how these values relate to behaviour, using a structure derived from factor analysis.

${ }^{1}$ Geert Hofstede, Gert Jan Hofstede, and Michael Minkov, Cultures and Organizations: Software of the Mind, 3rd ed. (New York: McGraw-Hill, 2010). 
This initial study is based on an international project (Tuning) currently taking place. The empirical data, derived from over 48,000 questionnaires, can offer a number of insights. In fact, one of the stages of Tuning project is a consultation process, namely, a survey to a set of different stakeholders (students, graduates, academics and employers), on the level of a) relevance and b) achievement of the generic and subject specific competences. The consultation was initially used in 2000 as a contact point within the different countries of the participating academics. In addition, it was a way of creating a common language among the different members of the group who belonged to different cultural contexts.

Since then it has become a goldmine producing comparable data from more than 103 countries in different continents, across a variety of disciplines and target groups. Not all the countries who elaborated and implemented a Tuning project used a questionnaire, selecting other different methodologies to evaluate opinion on the needs and demands of the social context. Other regions which did use the questionnaire method have not been discussed here, for example, Asian countries where the process is still taking place, although preliminary results confirms what is been presented in this paper.

Many questions could be asked and will be asked in future studies about the behaviour of each of the disciplines, the different social groups consulted, the evolution taking place and above all the implications and the impartial scrutiny of those results. The study described here also only relates to generic competences and does not go into the specificity of each of the fields available and comparable. This paper opens the dialogue and the academic debate. It explores commonality and differences in the competences selected in the different geographical contexts where the questionnaires have been used and offers some conclusions which can be drawn. There also are different roads to follow in terms of the analysis of the data on generic competences: (1) at the level of selection: by analysing which of the competences are selected (or not) in each of the projects which were conducted; (2) by measuring what was the level of commonality in this selection of generic competences; (3) by studying the level of difference among the generic competences in each project and (4) by analyzing whether there is any connection between the generic competences included in the list and the related geographic and cultural context.

\section{Some general definitions}

In the Tuning experience, and in the reflection on degree profiles, competences emerge as an important element which can guide the selection 
of what is appropriate from a wealth of possibilities. The trend towards a "learning society" has been widely accepted and consolidated for some time. This involves a move from teaching-centred to learning-centred education. Reflecting on the different aspects which characterise this trend, the relevance of focusing on competences becomes apparent.

Several terms -capacity, attribute, ability, skill- competence are used with an often interchangeable and, to some degree overlapping meaning. They all relate to the person and to what he/she is able to achieve. But they also have more specific meanings. The term skill is probably the most frequently used, with the meaning of being able, capable or skilful. It is often used in the plural, "skills," and sometimes with a more restricted meaning than that of competences.

Different cultural contexts influence the understanding of competence ${ }^{2}$ and this is especially important in relation to the extent to which competence is defined by cultural literacy involving group identities. There is such debate concerning the concept of competence that it is difficult to arrive at a definition capable of accommodating and reconciling all the different ways that the term is used. ${ }^{3}$ Describing competence as a "fuzzy concept" nonetheless acknowledges it as a "useful term, bridging the gap between education and job requirements". The difficulty of using competence as an overarching term as well a specific one is demonstrated by the tautological definition provided by: "Competency-based behavioural anchors are defined as performance capabilities needed to demonstrate knowledge, skill and ability (competency) acquisition". ${ }^{5}$

Competences tend to convey meaning in reference to what a person is capable or competent of in the degree of preparation, sufficiency and/or responsibility for certain tasks. ${ }^{6}$ Boyatzis ${ }^{7}$ defined competences as the certain characteristics or abilities of the person that enable him or her to demonstrate the appropriate specific actions, thereby leading to effective work performance.

2 Maria Cseh, "Facilitating learning in multicultural teams," Advances in Developing Human Resources 5, no. 1 (2003): 26-40.

3 David Robotham and Richard Jubb, "Competences: measuring the unmeasurable," Management Development Review 9, no. 5 (1996): 25-29.

${ }^{4}$ Jo Boon and Marcel van der Klink, "Competencies: The triumph of a fuzzy concept," in Academy of Human Resource Development Annual Conference, Honolulu, HA, 27 February - 3 March 2002, Proceedings Vol. 1, 327-334.

${ }^{5}$ Kim E. Dooley et al., "Behaviorally anchored competencies: evaluation tool for training via distance," Human Resource Development International 7, no. 3 (2004): 315-332.

${ }^{6}$ José María Prieto, prólogo to Gestión De Las Competencias, edited by Claude LevyLeboyer (Barcelona: Gestion 2000, 2002).

7 Richard E. Boyatzis, The Competent Manager: A Model for Effective Performance, John Wiley \& Sons (1982). 
In Tuning, the concept of competences tries to follow an integrated approach, looking at capacities via a dynamic combination of attributes that together permit a competent performance or as a part of a final product of an educational process. ${ }^{8}$ Competences and skills are understood as including knowing and understanding (theoretical knowledge of an academic field, the capacity to know and understand), knowing how to act (practical and operational application of knowledge to certain situations), knowing how to be (values as an integral element of the way of perceiving and living with others and in a social context). Competences represent a combination of attributes (with respect to knowledge and its application, attitudes, skills and responsibilities) that describe the level or degree to which a person is capable of performing them.

In this context, a competence or a set of competences mean that a person puts into play a certain capacity or skill and performs a task, where he/she is able to demonstrate that he/she can do so in a way that allows evaluation of the level of achievement. Competences can be demonstrated and assessed. It also means that normally a person does not either possess or lack a competence in absolute terms, but commands it to a varying degree, so that competences can be placed on a continuum.

In the Tuning Project ${ }^{9}$ two different sets of competences were focused on. The first identifies competences which could be general to any degree, and which are considered important by society. In a changing society where demands tend to be in constant reformulation, these generic competences assume a greater importance. The second set, specific competences, are those competences which are subject-area related. These are intimately related to the specific knowledge and practices of a field of study. These give identity and consistency to the particular degree programme.

This paper deals only with generic competences, agreed and consulted in 4 different regions through diverse Tuning projects.

One of the first tasks in every Tuning project was to identify the generic competences that should be developed in any programme, and which are considered important by society in a particular context or region. Defining these competences is the responsibility of academics, in consultation with other stakeholders, and the process followed was the same in all Tuning projects. The objective of the exercise is to place in the forefront of degree profiling the needs and the strengths of a particular society. Academics are therefore asked to reflect critically and to consult and discuss which are the competences that are

8 Yolanda Agudín, "La Educación Superior para el siglo XXI," Didac 36 (2000): 16-25.

9 Julia González and Robert Wagenaar, eds., Tuning educational structures in Europe: Final Report. Phase One (Bilbao: University of Deusto and University of Groningen, 2003). 
considered of the greatest relevance to the region where they live and work. The debates, given the limitations of the numbers that were imposed by questionnaire, are vigorous but always end in consensus. The inclusion and the formulation of every item is subject to serious discussion which is carried out in the different subject areas participating in each project (9 groups in Europe, 5 groups in Africa, 11 groups in Russia and 16 groups in Latin America).

In 2000 Tuning Europe was the first project to define competences, later revised in $2008 .{ }^{10}$ Europe agreed a list of 31 generic competences. Tuning Latin America in 2004 defined 27 generic competences ${ }^{11}$ for any university degree in the region. The academics taking part in Tuning Russia ${ }^{12}$ agreed to have 30 generic competences, while in Tuning Africa ${ }^{13} 18$ were defined, in both cases in 2011 .

The competences agreed in each region/country were defined, taking as a starting point the agreements reached in previous Tuning projects. Thus, there was feedback with respect to the identification of general competences in each context. Proof of this is the high level of agreement in the competences selected in each project. The agreed lists reflect what the project in its context considers essential to define a university degree. From this perspective, it is important to note that each list of generic competences presents a glimpse of the spirit of the region or country that proposes it. Contextual aspects are decisive for the inclusion of a competence and the exclusion of others in the list agreed. Also, the way they are proposed (phrasing) shows the perspective to be given to the context. The first statement of this study could be that the context determines the generic competences to include in the list of each region/country and the emphasis given to some (in cases in which the same competence in a region is broken up into two in another), and the way to present it in semantic terms. It is aspects of the cultural context that are decisive for the choice of competences, and even the phrasing of them demonstrates this, to the extent that what is seen as a single competence in one region may be described as two distinct ones in another.

${ }^{10}$ See the list of generic competences agreed by Europe $\mathrm{n}$ the Website of the Tuning Academy: http://www.tuningacademy.org

${ }_{11}$ Pablo Beneitone, César Esquetini, Julia González, Maida Marty Maleta, Gabriela Siufi, and Robert Wagenaar, eds., Reflections on and Outlook for Higher Education in Latin America. (Bilbao: University of Deusto, 2007).

12 Artur Demchuk, Ivan Dyukarev, Eygeniya Karavaeva, Pablo Beneitone, Julia González, and Robert Wagenaar, eds., Towards Comparability of Higher Education Programmes. Information Review (Bilbao: University of Deusto, 2013).

${ }^{13}$ Charles Awono Onana, Olusola Bandele Oyewole, Damtew Teferra, Pablo Beneitone, Julia González, and Robert Wagenaar, eds., Tuning and Harmonisation of Higher Education: The African Experience (Bilbao: University of Deusto, 2014). 

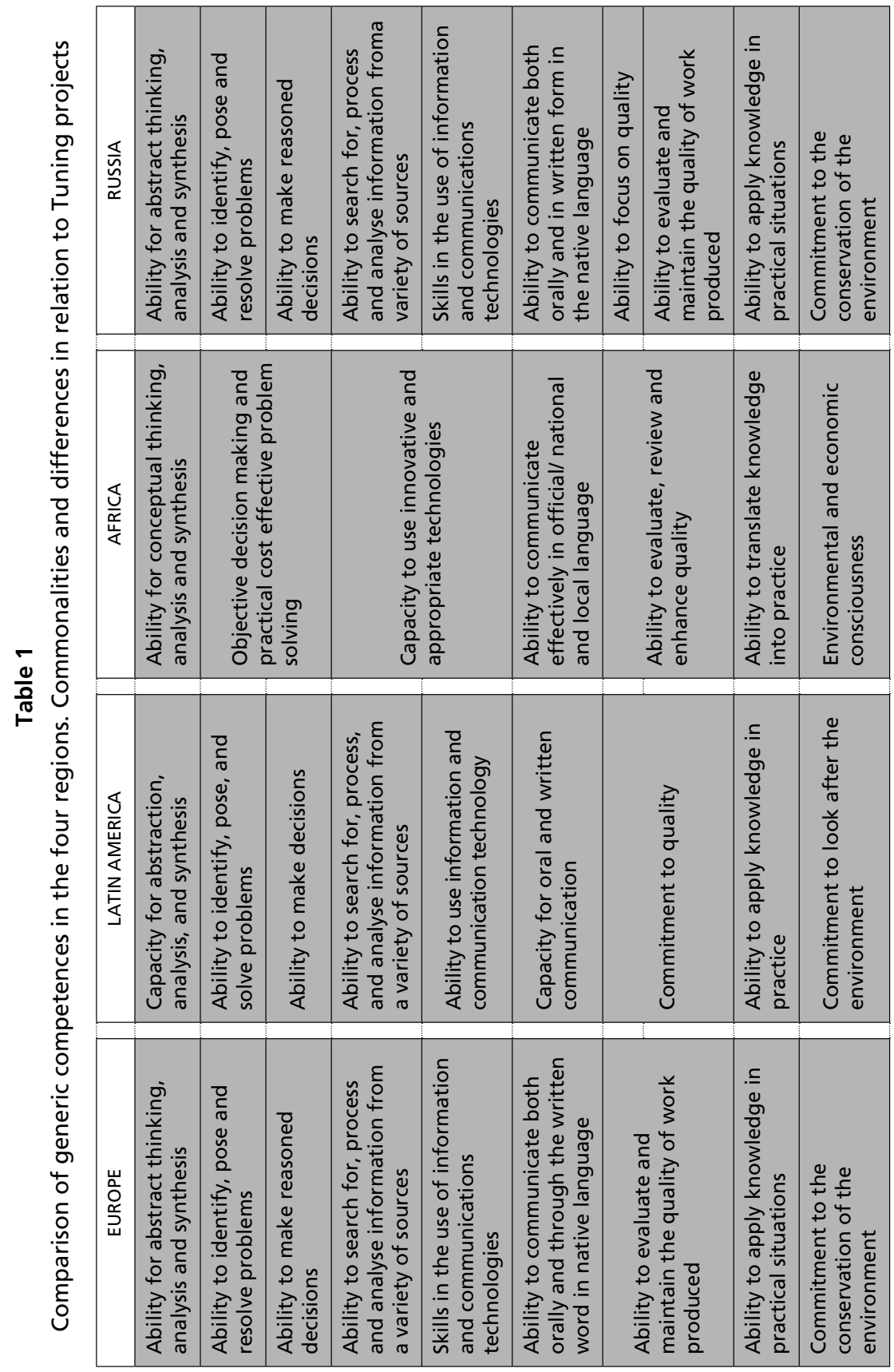


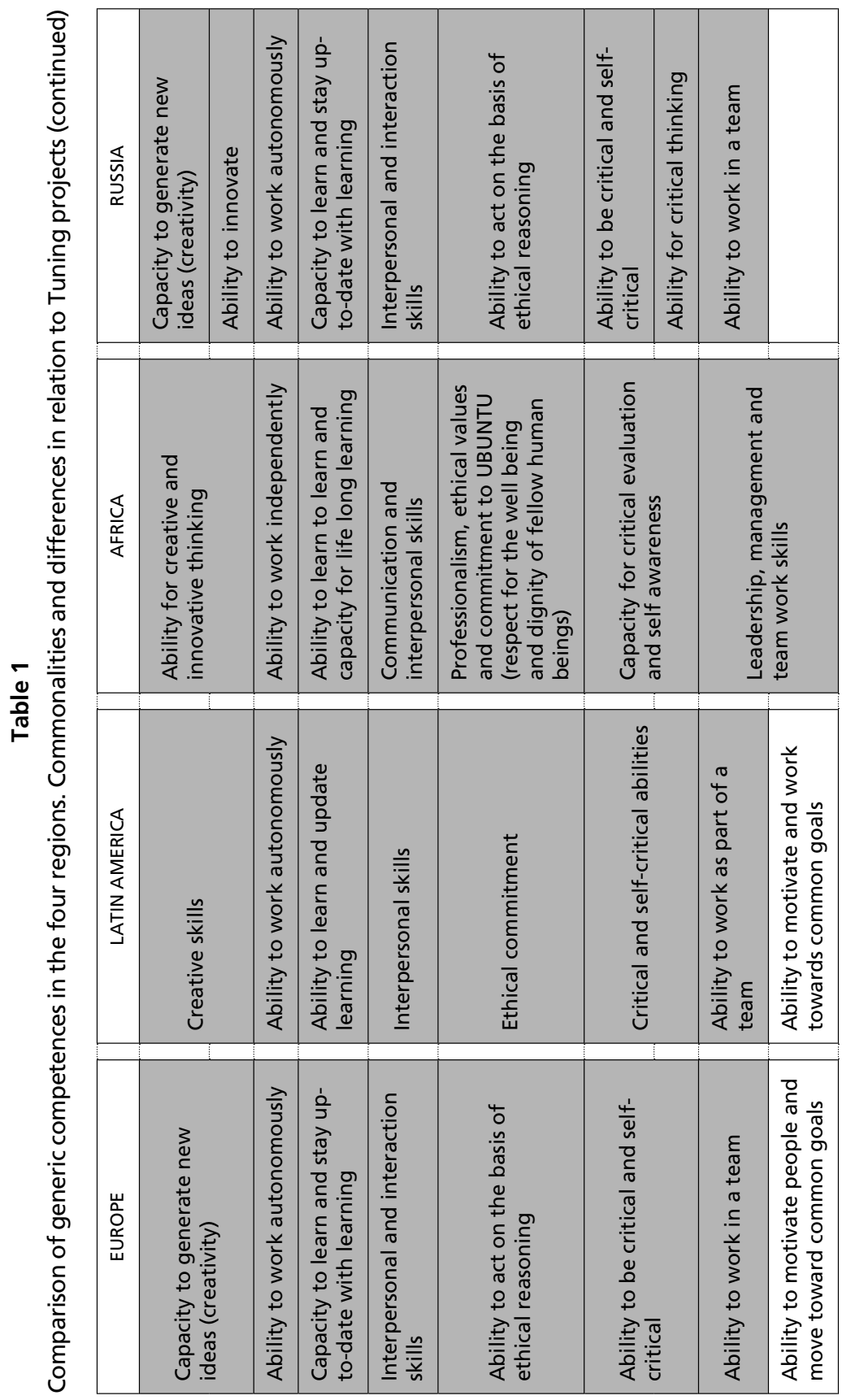




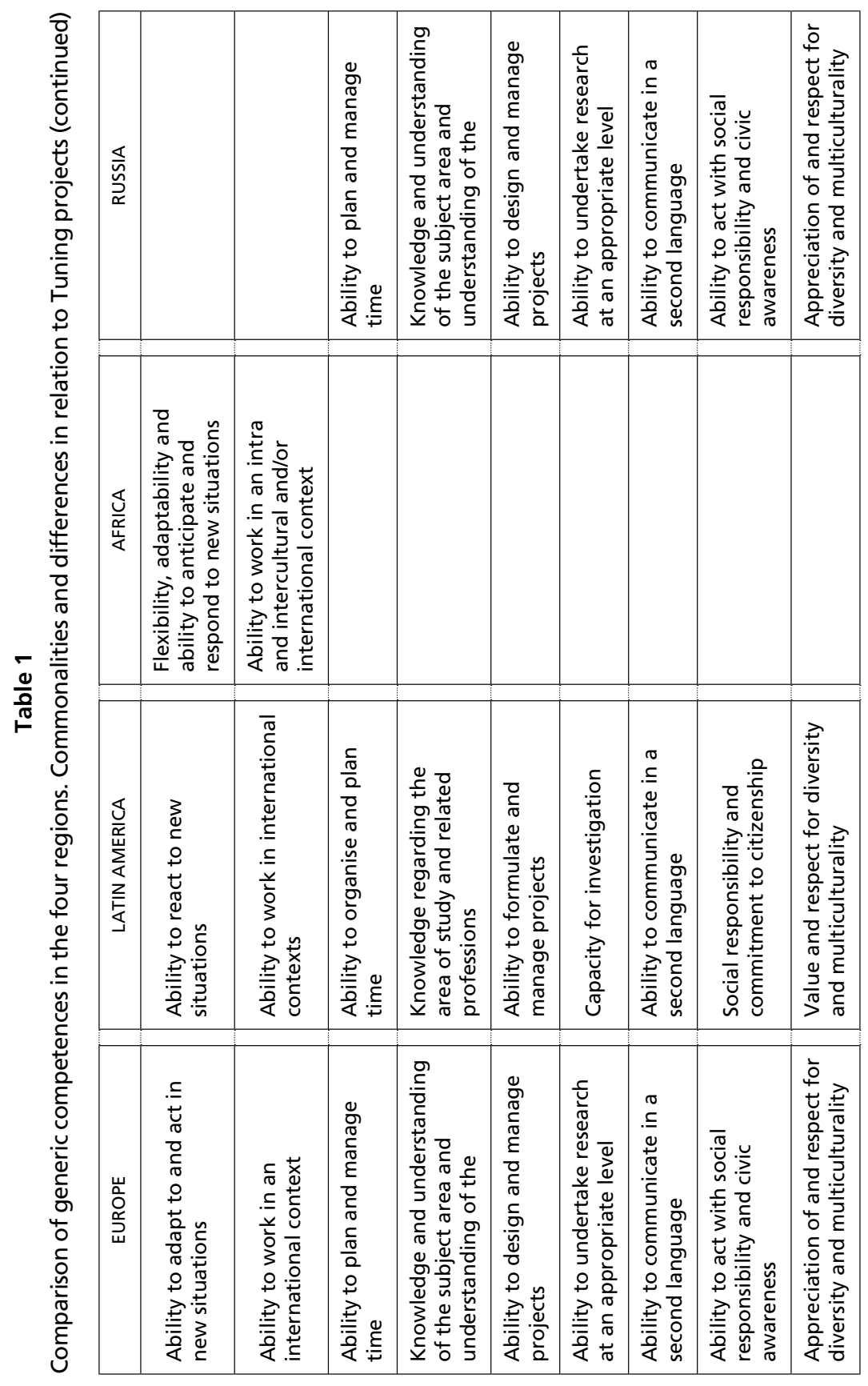




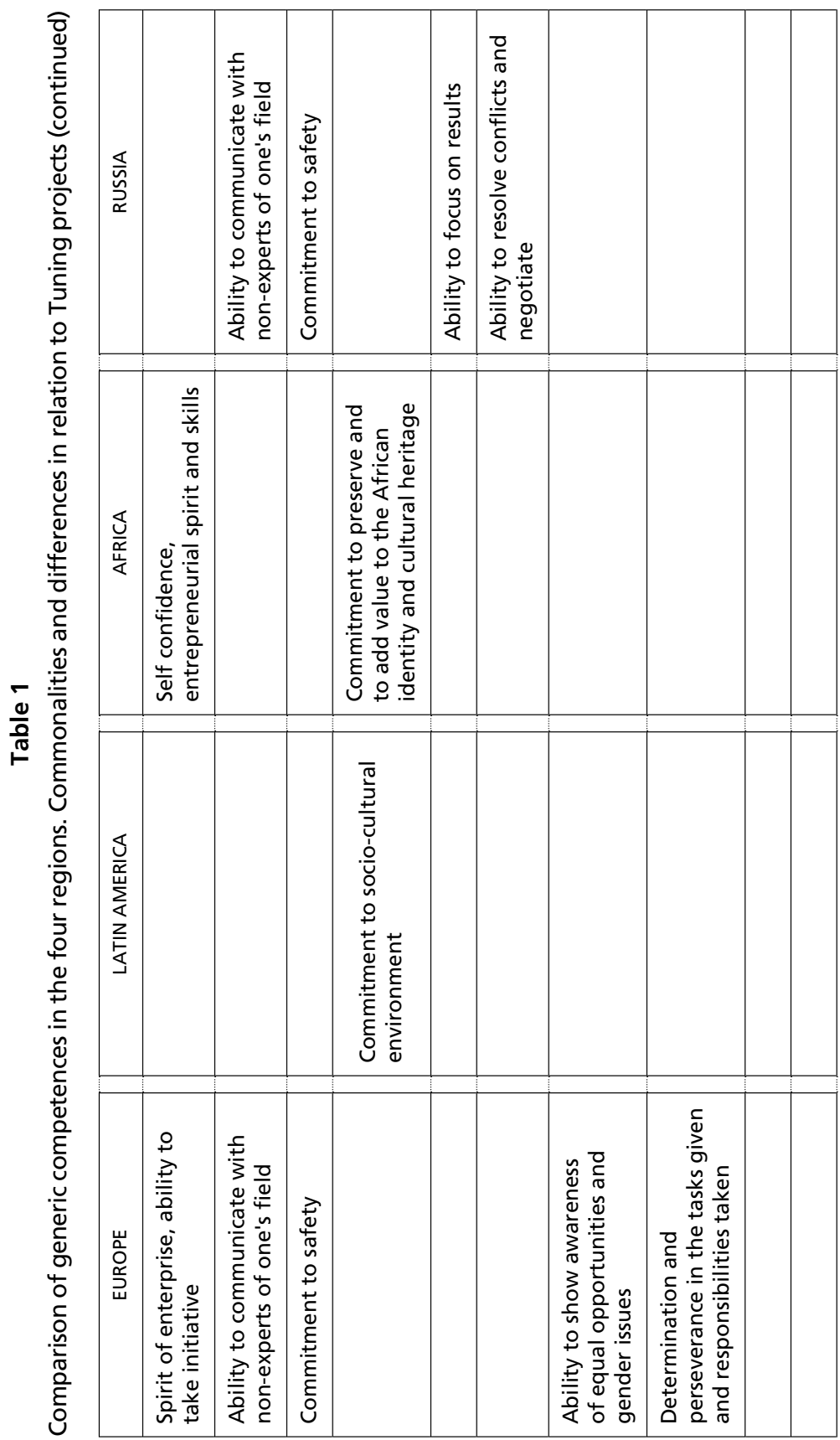


The first observation to make is in terms of formulation of the competences. As seen in Table 1 , there are 16 common generic competences in the 4 projects, 10 shared competences in 3 regions, 4 competences that are replicated in 2 regions and then 4 competences that appear only in one region but were not considered in the others. In the case of the competences identified as common, each region proposed a different formulation, but the essence of the competence was essentially the same.

This comparison of generic competences in the four regions shows that in some projects there are generic competences that point to the same focus but are described as more than one competence. For example in Russia, the competence related to quality, appears as two: Ability to focus on quality and Ability to evaluate and maintain the quality of work produced. Also in the same project, critical capabilities are reflected as two competences: Ability to be critical and self-critical and Ability for critical thinking. Similarly, Creativity is split into two competences: Capacity to generate new ideas (creativity) and Ability to innovate. This could be interpreted as the importance given in Russia to quality, creativity and critical thinking, requiring two competences that address each of the three aspects.

Unlike other regions, Africa defined only 18 generic competences, and in many cases incorporated more than one aspect into the formulation. This compact construction of the list of competences could reflect a more collective aspect of the context. In Africa, the agreements reached by academics in the definition of generic competences did not include aspects related to: Ability to plan and manage time; and manage project design; research skill; communicate in a second language; social responsibility and civic awareness; as well as knowledge regarding the subject area. In other cases, as Africa only identified 18 generic competences, some of them have in their definition more than one competence with respect to other regions. Such is the case for Problem solving and Decision making, that in the other three regions they appear as two separate competences and in Africa it is defined as Objective decision making and practical cost effective problem solving.

On the other hand in Russia, among the 30 competences, three were not included that appear in the other three regions: Ability to work in an international context; Leadership; and Ability to adapt to new situations. An open question for further discussion could be focused in relation to the non-inclusion of these competences in a Russian university degree profile.

There are two competences that appear only in Europe and Russia, which are: Ability to communicate with non-experts in the field; and Commitment to 
safety. Entrepreneurial spirit appears in Europe and Africa but it is not so relevant in Latin America and Russia.

Finally, there are 4 competences that occur in only one region. Russia identified Ability to focus on results and Ability to resolve conflicts and negotiate, which did not appear in other lists. Only Europe included the Ability to show awareness of equal opportunities and gender issues and Determination and perseverance in the tasks given and responsibilities taken.

The diversity of the identified generic competences in each context shows the peculiarities of regions, and highlights their local nature. However, the fact that 16 common competences were agreed indicates their global scope, and that is the focus of this paper. These 16 common generic competences can be organized into groups based on some underlying theory or logic (this is called classification ${ }^{14}$ of competences). Classification enhances theoretical and practical understanding ${ }^{15}$ and significance. ${ }^{16}$ According to Boyatzis ${ }^{17}$ there are different ways to classify competences. The two main options are organizing competences based on prior theory or classifying competences based on empirical evidence. Boyatzis further mentions several relationships that may exist among competences namely complimentary, compensatory, antagonism, and alternate manifestation depending on the nature of their influence and interaction with each other. Boyatzis asserts, as several competences can be related, there may also be a certain type of relationship between competence classes. Apart from debate on advantages and disadvantages of each of the methods, theoretical classification is a relatively easier and more stable framework to start with. Therefore, it seems to be a more prudent strategy to begin the comparative analysis with some basic predefined theoretical classification scheme for subsequent empirical analysis.

${ }^{14}$ Fotis Draganidis, Paraskevi Champoulou, and Gregoris Mentzas, "A Semantic Web Architecture for Integrating Competence Management and Learning Paths," Journal of Knowledge Management 12, no. 6 (2008): 121-136.

15 Anne Marelli, Janis Tondora, and Michael Hoge, "Strategies for Developing Competency Model," Administration and Policy in Mental Health 32, no. 5/6 (2005): 533-561.

${ }^{16}$ Charles Woodruffe, "What is Meant By Competency?", Leadership and Organizational Development Journal 14, no. 1 (1993): 29-36.

${ }^{17}$ Richard E. Boyatzis, Daniel Goleman, and Kenneth Rhee, "Clustering Competence in Emotional Intelligence Insights for the Emotional Competence Inventory," in Handbook of Emotional Intelligence, edited by Reuven Bar-On and James D. A. Parker (San Francisco: Jossey-Bass, 2000). 


\section{Theoretical classification}

In the literature, several ways of classifying competences are found. Researchers often classify competences ${ }^{18}$ based on their logic, theory and purpose of the study. ${ }^{19}$ In some education systems generic competences have been categorized and grouped into clusters. While there is considerable diversity in how generic competences are organized, there are some clusters of competences common to many taxonomies. Kemp and Seagraves ${ }^{20}$ in their review of the classifications developed in the United Kingdom Higher Education system identify the following grouping: written and verbal communication skills; interpersonal skills; numeracy and information technology. There are two international projects which conceptualise generic competences into categories: the OECD's Definition and Selection of Competences (DeSeCo) Project ${ }^{21}$ classifies generic competences into three broad categories as follows: Ability to use tools interactively; Ability to act in socially heterogeneous groups; and Ability to act autonomously. The $21^{\text {st }}$ century skills project ${ }^{22}$ uses four categories after consideration of a number of other conceptualizations as follows: Ways of thinking; Ways of working together; Tools for working; and Living in the world. The suggested broad-category conceptualization of generic competences for the Australian Qualification Framework (AQF) policy is: basic fundamental skills; people skills; thinking skills; and personal world view skills. Finally, the Dublin descriptors refer to the following five dimensions: 'knowledge and understanding'; 'applying knowledge and understanding'; 'making judgements'; 'communication'; and 'learning skills'.

All classifications described above follow different approaches. Since this article focuses on the experiences of the Tuning methodology in different regions

${ }^{18}$ Seing Youn Chyung, Donald Stepich, and David Cox, "Building a competency-based curriculum architecture to educate 21 st- century business practitioners," Journal of Education for Business July/August (2006): 307-314.

19 Jürgen Mühlbacher; Michaela Nettekoven, and Anna Putnová, "Competence Development in the Czech Republic," Journal of Global Business and Technology 5, no. 2 (2009).

20 Jan j. Kemp, and Liz Seagraves, "Transferable Skills--Can Higher Education Deliver?" Studies in Higher Education 20, no. 3 (1995):315-329. (Retrieved from Academic Search Premier on September 27, 2010).

${ }^{21}$ Dominique Simone Rychen and Laura Hersh Salganik, Key Competencies for a Successful Life and a Well-Functioning Society (Hogrefe Publishing GmbH, 2003).

${ }^{22}$ Kaye Bowman, Background paper for the AQF Council on generic skills. Australian Qualifications Framework Council (2010). 
we intend to use the Tuning in $2001^{23}$ classification of the generic competences. This classification divides the generic competences into three categories:

1. Instrumental Competences: Those having an instrumental function. They include:

- Cognitive abilities, capacity to understand and manipulate ideas and thoughts.

- Methodological capacities to manipulate the environment: organising time and strategies of learning, making decisions or solving problems.

- Technological skills related to use of technological devices, computing and information management skills.

- Linguistic skills such as oral and written communication or knowledge of a second language.

2. Interpersonal Competences: Individual abilities relating to the capacity to express one's own feelings, critical and self-critical abilities. Social skills relating to interpersonal skills or team-work or the expression of social or ethical commitment. These tend to favour processes of social interaction and of co-operation.

3. Systemic competences: those skills and abilities concerning whole systems. They suppose a combination of understanding, sensibility and knowledge that allows one to see how the parts of a whole relate and come together. These capacities include the ability to plan changes so as to make improvements in whole systems and to design new systems. Systemic competences require as a base the prior acquisition of instrumental and interpersonal competences.

Following the Tuning classification, the distribution of the $\mathbf{1 6}$ global generic competences in the four regions is as follows:

\section{Table 2}

Tuning classification of generic competences

Instrumental Competences

- Information management skills

- Computing skills

- Capacity for abstract thinking, analysis and synthesis

- Problem solving

- Decision making

- Oral and written communication

23 Julia González and Robert Wagenaar, eds., Tuning educational structures in Europe: Final Report. Phase One (Bilbao: University of Deusto and University of Groningen, 2003), 70-71. 
Table 2

Tuning classification of generic competences (continued)

Interpersonal Competences

— Interpersonal skills

- Critical and self-critical abilities

- Teamwork

- Ethical commitment

\section{Systemic Competences}

- Ability to apply knowledge in practice

- Concern for quality

- Commitment to the conservation of the environment

- Creativity

- Ability to work autonomously

- Capacity to learn actively

\section{Empirical categorisation}

As was explained, there are different theoretical classifications of generic competences but we can also categorize them as a result of empirical analysis. In all Tuning projects there is a consultation process following the initial definition of generic competences. Change and the variety of contexts both require a constant check on social demands for degree profiles. This underlines the need for consultation, and constant revision of information on adequacy. The language of competences could be considered more appropriate for consultation and dialogue with groups not directly involved in academic life, and can contribute to the necessary reflection for the development of new degrees and for permanent systems of updating existing ones. This enquiry was addressed to students, academics, employers and graduates, contacted by the academics participating in each Tuning project. The questionnaire consisted of the list of generic competences identified in each region. For each competence, the respondents were asked to indicate: 1) the importance of the competence, in his/her opinion, for work in their profession; and 2) the level of achievement of the competence that they estimated was reached as a result of taking their degree programme. To indicate this respondents were asked to use a scale of $1=$ none to $4=$ strong.

48,343 questionnaires were collected about generic competences, involving 82 countries, from 23 different subject areas and 410 universities 
around the world. The data relating to the sample participating in the 4 studies are presented below. Given the richness of the data collected and the possibilities offered, there is a need to focus and thus, this paper will concentrate only on one of the groups: the graduates.

\section{Table 3}

Tuning projects in the four regions.

Distribution of questionnaires received related to generic competences per group and per region

\begin{tabular}{|l|c|c|c|c|c|c|c|c|}
\cline { 2 - 9 } \multicolumn{1}{c|}{} & \multicolumn{2}{c|}{ Graduates } & \multicolumn{2}{c|}{ Employers } & \multicolumn{2}{c|}{ Academics } & \multicolumn{2}{c|}{ Students } \\
\cline { 2 - 9 } \multicolumn{1}{c|}{} & $\mathbf{N}$ & \multicolumn{1}{c|}{$\%$} & $\mathbf{N}$ & $\%$ & $\mathbf{N}$ & $\%$ & $\mathbf{N}$ & $\%$ \\
\hline Tuning Africa & $\mathbf{1 , 2 1 5}$ & $\mathbf{2 4 . 4}$ & $\mathbf{9 7 7}$ & 19.6 & 1,297 & 26 & 1,500 & 30 \\
\hline Tuning Europe & $\mathbf{1 , 9 4 8}$ & $\mathbf{2 6 . 5}$ & $\mathbf{8 7 9}$ & 12.4 & 2,041 & 28.8 & 2,219 & 31.3 \\
\hline Tuning Latin America & $\mathbf{8 , 4 6 2}$ & $\mathbf{3 0 . 9}$ & $\mathbf{2 , 2 7 8}$ & $\mathbf{8 . 3}$ & 5,443 & 19.9 & 11,215 & 40.9 \\
\hline Tuning Russia & $\mathbf{2 , 3 1 4}$ & $\mathbf{2 6}$ & $\mathbf{1 , 8 5 6}$ & 21 & $\mathbf{2 , 2 2 0}$ & 25 & 2,479 & 28 \\
\hline Total & $\mathbf{1 3 , 9 3 9}$ & $\mathbf{2 8 . 8}$ & $\mathbf{5 , 9 9 0}$ & $\mathbf{1 2 . 4}$ & $\mathbf{1 1 , 0 0 1}$ & $\mathbf{2 2 . 8}$ & $\mathbf{1 7 , 4 1 3}$ & $\mathbf{3 6}$ \\
\hline
\end{tabular}

Graduates represent $28.8 \%$ of the responses from the four regions and the correlation coefficient (Pearson's r) between graduates and the other groups (academics, students and employers) is over 0.88 in all the cases. Furthermore, they provide a real perspective on the importance of generic competences in study and in work, and of their achievement, having received a university education and then having entered society. This comparative analysis, therefore, focuses on the perceptions of graduates on the importance and achievement of competences.

It is intended to compare the perception of graduates from Africa, Europe, Latin America and Russia in relation to the generic competences defined for each context. For this, first the individual results of each study in relation to graduates are presented to enable comparison. We can then ask what is common and what is different in the graduates' valuation and grouping of the different generic competences?

\section{Methodology for the analysis}

In terms of methodology, two approaches have been taken. Firstly, a general overview of the average and variance on the generic competences helps us have a clear picture of the levels of two main indicators, importance 
and achievement; and secondly, the use of factor analysis to summarize the dimensions in every context.

In order to proceed with the first step of the analysis, we need to take into account that the data collected in Tuning surveys has a hierarchical structure, in the sense that individuals are nested in universities themselves, and universities are nested in countries, forming a hierarchical structure. A multilevel approach ${ }^{24}$ has been taken here, as the data, due to this clustering effect, are not fully independent from each other and the results cannot be considered as completely random.

To cope with this hierarchically structured data, an intra-class correlation needed to be calculated to check whether the differences between the aggregate units was high enough, and, therefore, to use the multilevel method for this purpose.

All the calculations of the data at university and country level were derived using this method as it takes into account, and controls for, the structure of data clustering. An additional advantage is that multilevel models allow the simultaneous appreciation of the difference at the individual respondent level and at the aggregate (university, subject area) level.

Once the clustering effect in the sample had been neutralized for comparison purposes, the mean scores for every generic competence were computed, in terms of the importance of the generic competence for the respondent, and in terms of the level of achievement the respondent believed has been reached for this particular competence in their context. The data analysis shows both measures, together with the average gap between importance and achievement.

The second approach has to do with the need to summarize information in every context and also identify the underlying dimensions behind the variables, in this case, the generic competences. In order to do this factor analysis was used as a method of data reduction, since it can take many variables and explain them with a few "factors" or "components". This method follows the logic that correlated variables are grouped together and separated from other variables with low or no correlation. If two items or dimensions are highly correlated, they are likely to represent highly related phenomena, and if they tell us about the same underlying variance in the data, combining them to form a single measure is reasonable. Once patterns of correlations are identified, the researcher provides an operational definition for the latent constructs and interprets them in terms of the substantive

${ }^{24}$ Anthony S. Bryk and Stephen W. Raudenbusch, Hierarchical Linear Models: Applications and Data Analysis Methods (Sage: Newbury Park, CA, 1992). 
meaning of the latent dimension extracted. This method ${ }^{25}$ is exploratory in the sense that it is not theory driven, and we cannot test a previous theory by creating a theoretical model; it basically extracts underlying dimensions based on the high correlation within the same factor and low correlation scores across factors. ${ }^{26}$

This method helps us to summarize all the information, and in our case helps to compare different contexts, as both the composition of the factors (based on correlation between the variables) and the number of factors extracted (differences in interpretation of the latent constructs) may be different, and these differences and similarities are what are interesting. The composition of the factors, and the number of dimensions, will provide important information on the composition and the latent structure of the generic competences across regions. In this paper, we have focused for the factor analyses in the importance of generic competences.

\section{Variance analysis}

The following table shows a comparison between the four regions in relation to the importance and achievement given by the graduates to the 16 global generic competences. The gap between the level of importance and the level of achievement implies a complementary aspect to be considered in the comparative analysis.

European graduates have an average of evaluation of competences between 3.67 and 2.85 on a scale of 1-4. They, therefore, consider that the competences are relevant. All competences are perceived to have had lower degree of achievement, between 3.1 and 2.21. The gap between importance and achievement has a range that goes from 0.4 to 1.14 where Ability to work autonomously seems to be showing the smallest difference between importance and achievement and Ability to apply knowledge in practical situations the largest difference. This result which tends to repeat itself all through the study proves that reality is always lower than the planned objectives. The relevant point, however is to realize the level of the gap and how this relates to the importance of the competence.

${ }^{25}$ Rudolph J. Rummel, Applied factor analysis (Evanston: Northwestern University Press, 1970).

${ }^{26} \mathrm{Kim}$ Jae On, Introduction to Factor Analysis: What It Is and How To Do It (California: Sage, 1978). 


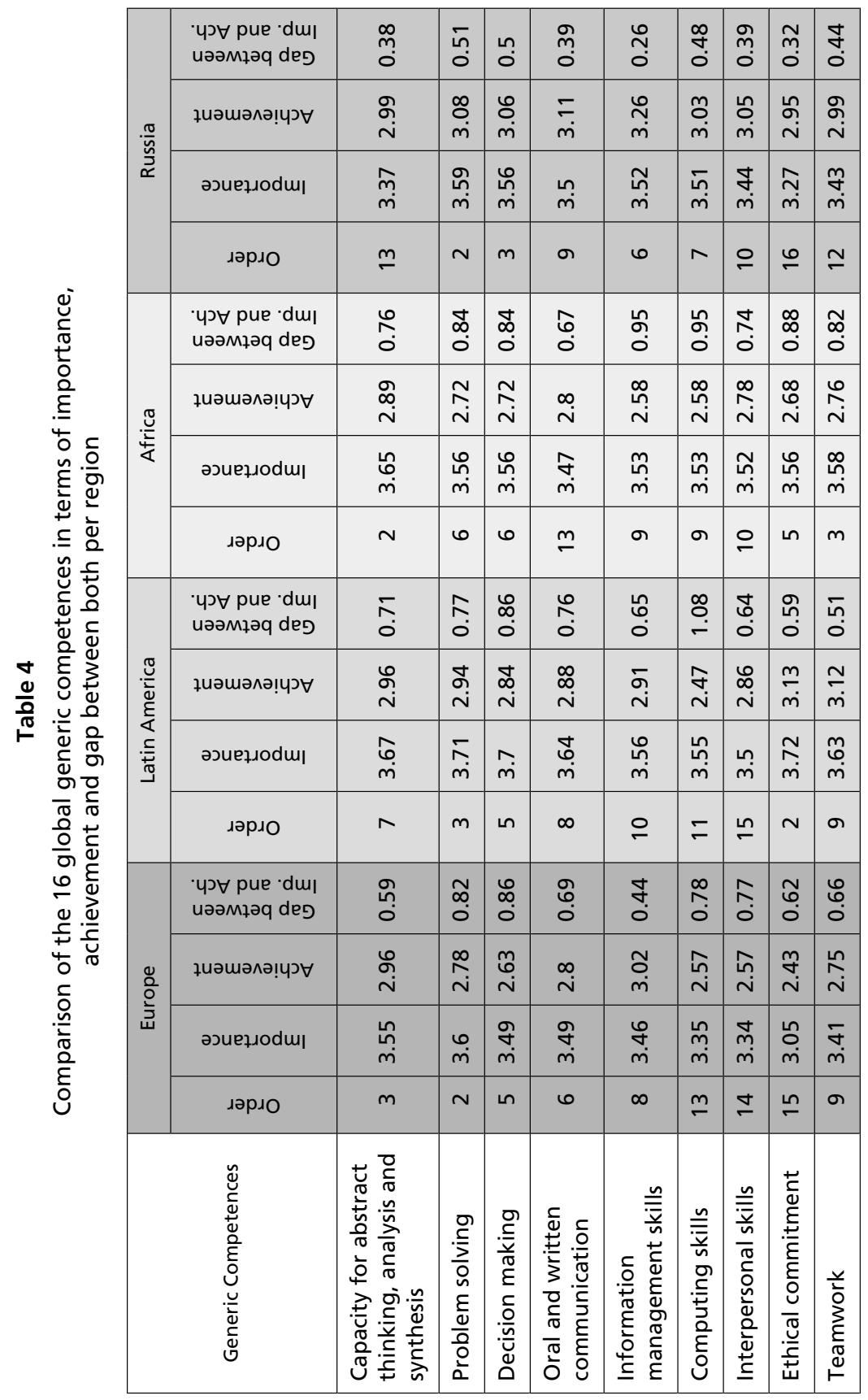




\begin{tabular}{|c|c|c|c|c|c|c|c|c|c|c|c|}
\hline & & $\begin{array}{l}\text { чગ } \forall \text { pue } \cdot d u l \\
\text { uәәмұəq deэ }\end{array}$ & $\stackrel{m}{m}$ & or & กึ? & $\stackrel{\infty}{\leftrightarrow}$ & \begin{tabular}{l|l}
$\stackrel{\infty}{+}$ & \multirow{f}{0}{} \\
\multirow{0}{*}{} & 0
\end{tabular} & $\stackrel{\sim}{m}$ & ঙั & $\underset{0}{0}$ & $\hat{n}$ \\
\hline & $\cdot \frac{\pi}{n}$ & ұиәшәлә!чગ & $\stackrel{m}{\text { ò }}$ & $\begin{array}{l}\infty \\
\infty \\
i\end{array}$ & $\begin{array}{l}\hat{\sigma} \\
i\end{array}$ & $\stackrel{\infty}{i}$ & \begin{tabular}{l|l}
$\tilde{O}$ & $\mathscr{0}$ \\
$\dot{m}$ & $\dot{m}$
\end{tabular} & $\stackrel{\hat{\sigma}}{i}$ & 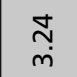 & مે & $\begin{array}{l}\hat{0} \\
\dot{m}\end{array}$ \\
\hline & $\stackrel{\vec{\nu}}{\sim}$ & әзиедоодшा & $\stackrel{\mathscr{m}}{m}$ & 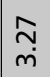 & $\stackrel{\sim}{m}$ & $\stackrel{m}{m}$ & $\begin{array}{ll}n & m \\
m & m\end{array}$ & ๙ু & 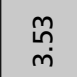 & $\begin{array}{l}\ddot{\ell} \\
\dot{m}\end{array}$ & $\stackrel{\text { 巳ে }}{m}$ \\
\hline & & ләрцо & $\approx$ & $\stackrel{n}{\sim}$ & $\stackrel{\infty}{\circ}$ & $\Xi$ & $\infty \quad \nabla$ & $\stackrel{\text { ㅁ }}{-}$ & in & - & $=$ \\
\hline 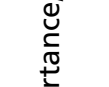 & & $\begin{array}{l}\text { чગ } \forall \text { pue } \cdot d u l \\
\text { uәәмұəq deפ }\end{array}$ & $\bar{\alpha}$ & & o & & 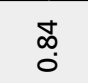 & $\underset{\infty}{\infty}$ & $\hat{0}$ & $\stackrel{\infty}{\infty}$ & $\stackrel{\infty}{0}$ \\
\hline $\begin{array}{l}\text { 응 } \\
\text { 들 }\end{array}$ & ల్ల & ұиәшәлә!чગ & 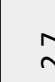 & & $\stackrel{\bullet}{\bullet}$ & & $\stackrel{i}{i}$ & $\stackrel{\text { ஸे }}{\text { N }}$ & $\stackrel{\substack{\infty \\
i}}{\sim}$ & $\stackrel{\infty}{i}$ & $\stackrel{\substack{N \\
i}}{i}$ \\
\hline है & 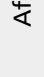 & әэuедоodur & in & & $\begin{array}{l}\mathscr{L}^{n} \\
m\end{array}$ & & $\begin{array}{l}\stackrel{\operatorname{Ln}}{\kappa n} \\
\text { m }\end{array}$ & $\stackrel{\stackrel{n}{m}}{m}$ & $\stackrel{\substack{n \\
m}}{m}$ & $\begin{array}{l}\stackrel{0}{6} \\
\dot{m}\end{array}$ & $\underset{m}{f}$ \\
\hline$\subseteq \frac{\overline{0}}{\mathrm{~s}}$ & & ләрдо & $=$ & & $\checkmark$ & & $\Lambda$ & $\Xi$ & $\infty$ & - & $\simeq$ \\
\hline 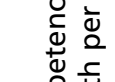 & & $\begin{array}{l}\text { чગ } \forall \text { pue d dul } \\
\text { uәәмұəq deg }\end{array}$ & $\bar{c}$ & & $\stackrel{\infty}{0}$ & & ஸै & $\begin{array}{c}\infty \\
\infty \\
0\end{array}$ & @़ & $\begin{array}{l}0 \\
\infty \\
0\end{array}$ & $\begin{array}{l}0 \\
0 \\
0\end{array}$ \\
\hline$\left\{\begin{array}{l}\bar{\varepsilon} \\
\mathcal{O} \\
\mathcal{u}\end{array}\right.$ & है & ұиәшәлә!чว & $\propto$ & & $\stackrel{m}{n}$ & & $\bar{m}$ & 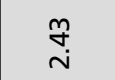 & $\begin{array}{l}m \\
\infty \\
N\end{array}$ & $\stackrel{\bar{\infty}}{i}$ & ๙ั \\
\hline 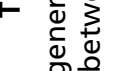 & 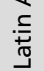 & әзиедиоdm| & $\begin{array}{l}\text { ñ } \\
\text { r } \\
\text { r }\end{array}$ & & $\stackrel{m}{m}$ & & $\stackrel{N}{n}$ & $\stackrel{\stackrel{n}{n}}{m}$ & กิ & $\stackrel{\hat{b}}{m}$ & $\bar{i}$ \\
\hline $\begin{array}{ll}\bar{\pi} & 0 \\
\frac{0}{0} & 0\end{array}$ & & ләр АО & $\stackrel{m}{2}$ & & $\simeq$ & & - & 6 & 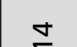 & 6 & $\nabla$ \\
\hline $\begin{array}{ll}0 & \frac{1}{\sigma} \\
0 & \frac{1}{d}\end{array}$ & & 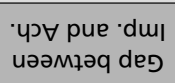 & i & & ठํ & & $\hat{\sigma}$ & ఫ্ّ & 옹 & 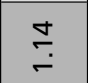 & นீ \\
\hline 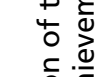 & \% & ұиәшәлә!чว & है & & $\stackrel{\sim}{\sim}$ & & $\bar{N}$ & $\underset{\sim}{N}$ & $\dot{m}$ & $\stackrel{n}{n}$ & ๙ู \\
\hline 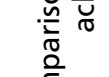 & سُ & әэиедооди & $\stackrel{\substack{r \\
r}}{r}$ & & $\begin{array}{l}\dot{m} \\
m\end{array}$ & & $\stackrel{\infty}{m}$ & $\begin{array}{l}\stackrel{L}{\infty} \\
\sim \\
\sim\end{array}$ & $\stackrel{\ln }{m}$ & $\stackrel{\hat{b}}{\dot{m}}$ & $\stackrel{\infty}{\stackrel{\infty}{\dot{m}}}$ \\
\hline$\overline{0}$ & & ләрцо & c & 으 & $\simeq$ & & $\mp$ & $\underline{6}$ & $\checkmark$ & - & N \\
\hline & & 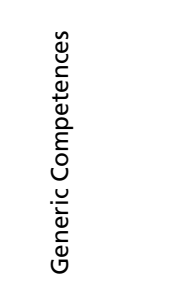 & 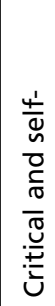 & 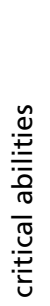 & 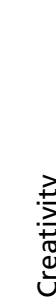 & & 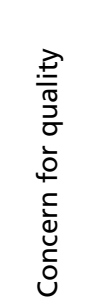 & 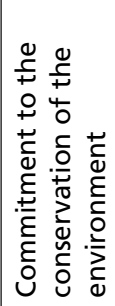 & 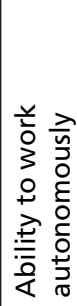 & 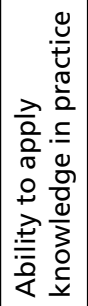 & 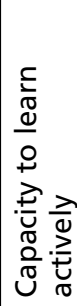 \\
\hline
\end{tabular}


African graduates have an average of evaluation of competences between 3.68 and 3.35 on a scale of $1-4$, meaning that the selection of the competences was perceived as very relevant, and therefore the institutions should concentrate in the development of these selected competences. All competences are perceived with a lower degree of achievement, between 2.81 and 2.54. The gap between importance and achievement has a range that goes from 0.67 to 0.95 where Ability to communicate effectively in officiall national and local language shows the smallest difference between importance and achievement and Capacity to use innovative and appropriate technologies the largest.

Latin American graduates have an average evaluation of competences between 3.72 and 3.25. The similarity of the degree of perceived importance between the African and the Latin American graduates is noteworthy. Again, all competences are perceived with a lower degree of achievement, between 3.13 and 2.43, the largest range compared with other regions. The gap between importance and achievement has a range that goes from 0.51 to 1.08 where Ability to work as part of a team shows the smallest difference between importance and achievement and Ability to use information and communication technologies the largest.

The results for Russia are very similar but with a bigger gap. Russian graduates have an average evaluation of the importance of the competences between 3.66 and 2.99. All competences are perceived with a lower degree of achievement, between 3.26 and 2.67. The gap between importance and achievement has a range that goes from 0.26 to 0.67 where Skills in the use of information and communication technologies shows the smallest difference between importance and achievement and Ability to apply knowledge in practical situations the largest.

In terms of importance, graduates in all four regions identified two competences among the top six: Problem solving and Capacity to apply knowledge in practice. There are also two competences at the bottom in all four regions: Commitment to the conservation of the environment and Critical and self-critical abilities. There are other competences which in some regions are considered very important and less important in others: Capacity to learn actively is clearly one of the most important for Europe and Latin America but it is rated among the least important in Africa and Russia. Ethical commitment is very important in Latin America and Africa but less important in Europe and Russia.

Graduates in all four regions rated three competences among the five with the largest gap between level of importance and level of achievement: Ability to apply knowledge in practice, Creativity and Decision-making. While Russian graduates considered that Computer skills is one of the 
competences with the smallest gap between importance and achievement, Latin American and African graduates perceived this competence to have the largest gap. This reflects an important difference, in that a competence may be rated similarly in all contexts, but differences in achievement point to the fact that this may be problematic in some regions and not in others.

The attempts to unfold the reasoning behind these differences in the perception and valuing of different competences in each of the regions can enrich the understanding of cultural perceptions of needs and is a field which offers a great capacity for further research.

\section{Factor analysis}

The factor analysis by region shows differences in the way the 16 generic competences are grouped according to the perspectives of graduates. Russia shows 4 factors, Europe 3 factors, Latin America and Africa only 1 factor each.

The factorial analysis of the 16 global competences has the following features from the perspective of Russian graduates:

\section{Table 5}

Rotated factor matrix for generic competences in Russia: Graduates

\begin{tabular}{|c|c|c|c|c|c|}
\hline \multirow{2}{*}{ Factor } & \multirow{2}{*}{ Competence } & \multicolumn{4}{|c|}{ Component } \\
\hline & & 1 & 2 & 3 & 4 \\
\hline \multirow{8}{*}{1} & $\begin{array}{l}\text { Ability to evaluate and maintain the } \\
\text { quality of work produced }\end{array}$ & 0.957 & 0.085 & -0.005 & 0.103 \\
\hline & $\begin{array}{l}\text { Ability to search for, process and } \\
\text { analyse information from a variety of } \\
\text { sources }\end{array}$ & 0.957 & 0.098 & -0.016 & 0.097 \\
\hline & Interpersonal and interaction skills & 0.951 & 0.084 & 0.000 & 0.112 \\
\hline & Ability to be critical and self-critical & 0.938 & 0.071 & -0.009 & 0.130 \\
\hline & Ability to focus on quality & 0.913 & 0.175 & 0.045 & 0.016 \\
\hline & Ability to innovate & 0.896 & 0.153 & 0.070 & 0.003 \\
\hline & $\begin{array}{l}\text { Commitment to the conservation of } \\
\text { the environment }\end{array}$ & 0.711 & -0.067 & 0.061 & 0.424 \\
\hline & $\begin{array}{l}\text { Ability to act on the basis of ethical } \\
\text { reasoning }\end{array}$ & 0.650 & -0.052 & 0.094 & 0.541 \\
\hline
\end{tabular}


Table 5

Rotated factor matrix for generic competences in Russia: Graduates (continued)

\begin{tabular}{|c|l|c|c|c|c|}
\hline \multirow{2}{*}{ Factor } & \multicolumn{3}{|c}{ Competence } & \multicolumn{3}{c|}{ Component } \\
\cline { 3 - 6 } & & 1 & 2 & 3 & 4 \\
\hline \multirow{2}{*}{2} & Ability to work autonomously & 0.029 & 0.738 & 0.121 & 0.156 \\
\cline { 2 - 6 } & $\begin{array}{l}\text { Capacity to learn and stay up-to-date } \\
\text { with learning }\end{array}$ & 0.059 & 0.704 & 0.191 & 0.047 \\
\cline { 2 - 6 } & $\begin{array}{l}\text { Ability to communicate both orally } \\
\text { and in written form in the native } \\
\text { language }\end{array}$ & 0.081 & 0.628 & 0.202 & 0.145 \\
\cline { 2 - 6 } & $\begin{array}{l}\text { Ability to identify, pose and resolve } \\
\text { problems }\end{array}$ & 0.098 & 0.511 & 0.470 & -0.161 \\
\hline \multirow{2}{*}{3} & $\begin{array}{l}\text { Capacity to generate new ideas } \\
\text { (creativity) }\end{array}$ & -0.055 & 0.144 & 0.726 & 0.046 \\
\cline { 2 - 6 } & Ability to work in a team & 0.023 & 0.141 & 0.722 & 0.090 \\
\cline { 2 - 6 } & $\begin{array}{l}\text { Ability for abstract thinking, analysis } \\
\text { and synthesis }\end{array}$ & -0.065 & 0.131 & 0.718 & 0.139 \\
\cline { 2 - 6 } & $\begin{array}{l}\text { Ability to apply knowledge in } \\
\text { practical situations }\end{array}$ & 0.206 & 0.398 & 0.487 & -0.015 \\
\hline & $\begin{array}{l}\text { Skills in the use of information and } \\
\text { communications technologies }\end{array}$ & 0.099 & 0.418 & 0.462 & 0.095 \\
\hline \multirow{2}{*}{4} & Ability for critical thinking & 0.210 & 0.211 & 0.162 & 0.779 \\
\hline & Ability to make reasoned decisions & 0.190 & 0.488 & 0.102 & 0.573 \\
\hline
\end{tabular}

$67,12 \%$ variance explained.

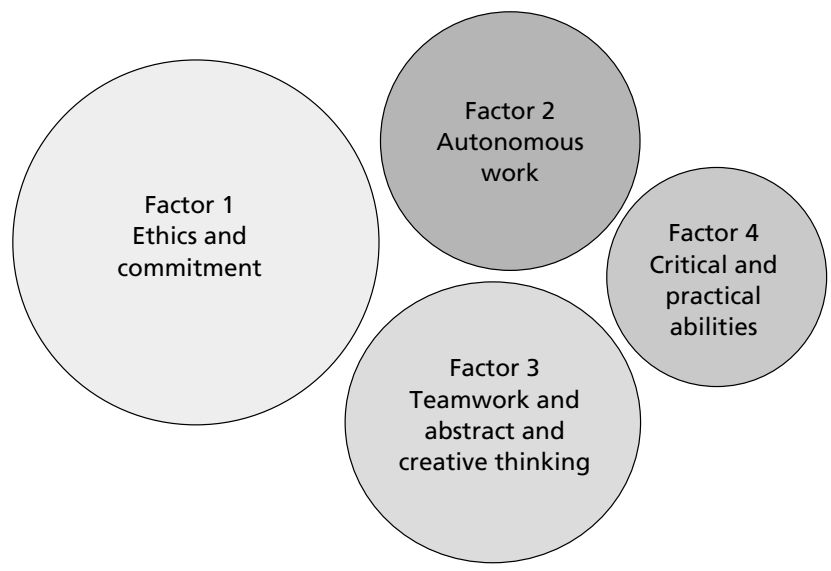

Figure 1

Interpretation of factors for Graduates in Russia 
For the case of Russian graduates, four factors have been extracted, with slight differences from the European and Latin American graduates. Ethics and commitment (factor 1) constitutes for Russian graduates a factor on its own, and so does Analysis and autonomous work (factor 2). Factor 3 is called Teamwork, abstract and creative thinking, as it is composed of competences such as abstract thinking, creativity and teamwork. Critical thinking and reasoned decision making constitute a factor on its own, suggesting specific and distinctive relevance of these two competences, which can be interpreted as Critical and practical abilities (factor 4).

Returning to the classification used in Tuning of instrumental, interpersonal and systemic competences, and crossing this categorization with the factors, Table 5a shows that in factor 1 there is a greater presence of systemic competences, factor 2 and 3 have a balance between instrumental and systemic competences. Factor 4 does not show a strong relationship with any of the three theoretical categories.

The factorial analysis of the 16 global competences has the following features from the perspective of European graduates:

\section{Table 6}

Rotated factor matrix for generic competences in Europe: Graduates

\begin{tabular}{|c|l|c|c|c|}
\hline \multirow{2}{*}{ Factor } & \multicolumn{3}{|c|}{ Competence } & \multicolumn{3}{|c|}{ Component } \\
\cline { 3 - 5 } & & 1 & 2 & 3 \\
\hline \multirow{7}{*}{1} & $\begin{array}{l}\text { Ability for abstract thinking, analysis and } \\
\text { synthesis }\end{array}$ & 0.627 & -0.068 & -0.048 \\
\hline $\begin{array}{l}\text { Ability to search for, process and analyse } \\
\text { information from a variety of sources }\end{array}$ & 0.626 & 0.029 & 0.140 \\
\hline & $\begin{array}{l}\text { Ability to identify, pose and resolve } \\
\text { problems }\end{array}$ & 0.607 & 0.254 & 0.106 \\
\hline & Ability to work autonomously & 0.594 & 0.174 & -0.070 \\
\hline & \begin{tabular}{l} 
Capacity to generate new ideas (creativity) \\
\cline { 2 - 5 }
\end{tabular} & 0.559 & 0.023 & 0.332 \\
\hline $\begin{array}{l}\text { Capacity to learn and stay up-to-date with } \\
\text { learning }\end{array}$ & 0.538 & 0.188 & 0.216 \\
\hline & Ability to be critical and self-critical & 0.517 & 0.256 & 0.123 \\
\hline & $\begin{array}{l}\text { Skills in the use of information and } \\
\text { communications technologies }\end{array}$ & 0.337 & 0.220 & 0.184 \\
\hline
\end{tabular}




\section{Table 6}

Rotated factor matrix for generic competences in Europe: Graduates (continued)

\begin{tabular}{|c|c|c|c|c|}
\hline \multirow{2}{*}{ Factor } & \multirow{2}{*}{ Competence } & \multicolumn{3}{|c|}{ Component } \\
\hline & & 1 & 2 & 3 \\
\hline \multirow{5}{*}{2} & Interpersonal and interaction skills & 0.005 & 0.781 & 0.143 \\
\hline & Ability to work in a team & -0.009 & 0.737 & 0.205 \\
\hline & $\begin{array}{l}\text { Ability to communicate both orally and } \\
\text { through the written word in native } \\
\text { language }\end{array}$ & 0.230 & 0.510 & -0.003 \\
\hline & Ability to make reasoned decisions & 0.350 & 0.489 & 0.180 \\
\hline & $\begin{array}{l}\text { Ability to apply knowledge in practical } \\
\text { situations }\end{array}$ & 0.233 & 0.374 & 0.249 \\
\hline \multirow{3}{*}{3} & $\begin{array}{l}\text { Commitment to the conservation of the } \\
\text { environment }\end{array}$ & 0.055 & 0.102 & 0.816 \\
\hline & $\begin{array}{l}\text { Ability to act on the basis of ethical } \\
\text { reasoning }\end{array}$ & 0.078 & 0.255 & 0.753 \\
\hline & $\begin{array}{l}\text { Ability to evaluate and maintain the } \\
\text { quality of work produced }\end{array}$ & 0.392 & 0.204 & 0.490 \\
\hline
\end{tabular}

$43,21 \%$ Variance explained

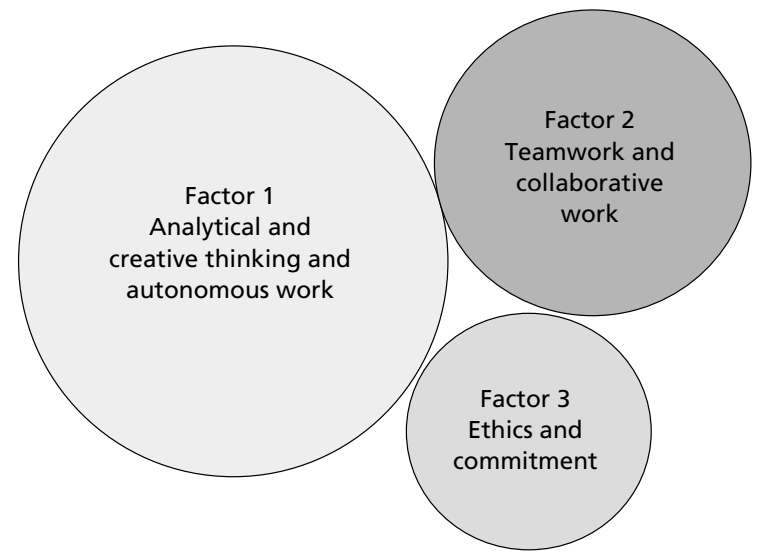

Figure 2

Interpretation of the factors for graduates in Europe 
For Europe, a possible way to classify the competences according to their grouping in dimensions or factors would be by interpreting the first factor as composed of competences addressing Analytical and creative thinking and autonomous work as they focus in autonomous work, analysis and information processing. The competences which comprise the second factor could be interpreted as Teamwork and collaborative work. The competences configuring factor two are mainly related to communication skills, decision making and teamwork. Factor three can be interpreted as Ethics and commitment, as it includes those competences related to ethics, commitment to environment, quality etc.

In factor 1 there is a higher proportion of instrumental competences, factor 2 is divided into systemic and interpersonal competences and factor 3 is clearly identified with systemic competences.

The factorial analysis of the 16 global competences has the following features from the perspective of Latin American graduates:

Table 7

Rotated factor matrix for generic competences in Latin America: Graduates

\begin{tabular}{|c|c|c|c|}
\hline \multirow{2}{*}{ Factor } & \multirow{2}{*}{ Competence } & \multicolumn{2}{|c|}{ Component } \\
\hline & & 1 & 2 \\
\hline \multirow{9}{*}{1} & Capacity for abstraction, analysis, and synthesis. & 0.714 & 0.074 \\
\hline & Ability to learn and update learning. & 0.710 & 0.217 \\
\hline & $\begin{array}{l}\text { Ability to search for, process, and analyse } \\
\text { information from a variety of sources. }\end{array}$ & 0.658 & 0.271 \\
\hline & Capacity for oral and written communication. & 0.630 & 0.271 \\
\hline & Ability to identify, pose, and solve problems. & 0.621 & 0.385 \\
\hline & Ability to apply knowledge in practice. & 0.596 & 0.158 \\
\hline & Critical and self-critical abilities. & 0.551 & 0.362 \\
\hline & $\begin{array}{l}\text { Ability to use information and communication } \\
\text { technology. }\end{array}$ & 0.540 & 0.324 \\
\hline & Ability to work autonomously. & 0.467 & 0.387 \\
\hline
\end{tabular}


Table 7

Rotated factor matrix for generic competences in Latin America: Graduates (continued)

\begin{tabular}{|c|l|r|r|}
\hline \multirow{2}{*}{ Factor } & \multicolumn{1}{|c|}{ Competence } & \multicolumn{2}{c|}{ Component } \\
\cline { 3 - 4 } & & 1 & \multicolumn{1}{c|}{2} \\
\hline \multirow{3}{*}{2} & Ability to work as part of a team. & 0.217 & 0.713 \\
\cline { 2 - 4 } & Interpersonal skills. & 0.235 & 0.711 \\
\cline { 2 - 4 } & Commitment to look after the environment & 0.058 & 0.668 \\
\cline { 2 - 4 } & Ethical commitment. & 0.367 & 0.601 \\
\cline { 2 - 4 } & Ability to make decisions. & 0.407 & 0.591 \\
\cline { 2 - 4 } & Commitment to quality. & 0.416 & 0.549 \\
\cline { 2 - 4 } & Creative skills. & 0.446 & 0.446 \\
\hline
\end{tabular}

$47,58 \%$ Variance explained

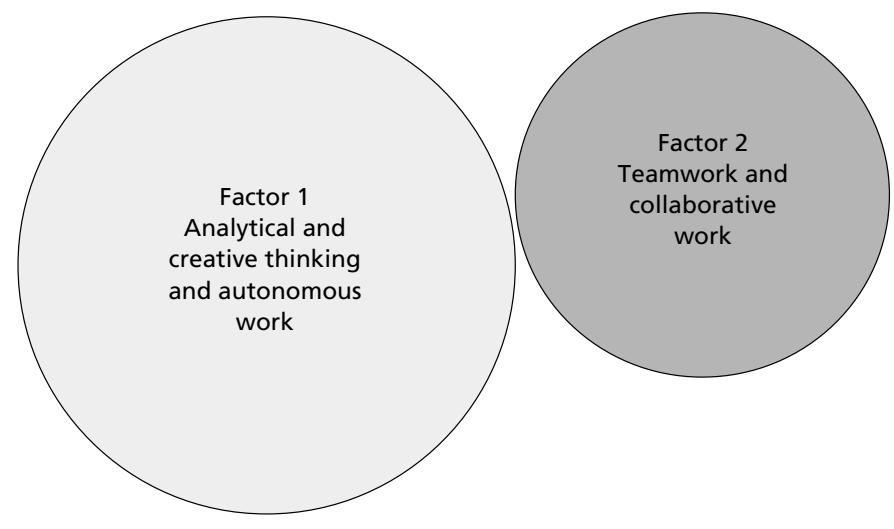

Figure 3

Interpretation of factors for graduates in Latin America

Two main factors were extracted for the Latin America experience. From graduates the groupings and the composition of each factor, the following interpretation can be made; a first factor addresses those competences related to Analytical and creative thinking and autonomous work, and the second factor can be interpreted as Teamwork and collaborative work. We can 
immediately note a difference with the European graduates, in the sense that ethical and commitment skills do not constitute a factor on its own, but those competences are distributed across the two factors.

Analysing the factors with the Tuning classification we can see that factor 1 is closely linked to instrumental competences and in factor 2 there is a balanced presence of systemic and interpersonal competences.

The factorial analysis of the 16 global competences has the following features from the perspective of African graduates:

Table 8

Rotated factor matrix for generic competences in Africa: Graduates

\begin{tabular}{|c|c|c|}
\hline \multirow{2}{*}{ Factor } & \multirow{2}{*}{ Competence } & Component \\
\hline & & 1 \\
\hline \multirow{14}{*}{1} & Ability for creative and innovative thinking & 0.750 \\
\hline & Communication and interpersonal skills & 0.735 \\
\hline & $\begin{array}{l}\text { Capacity to use innovative and appropriate } \\
\text { technologies }\end{array}$ & 0.734 \\
\hline & Ability to evaluate, review and enhance quality & 0.725 \\
\hline & $\begin{array}{l}\text { Objective decision making and practical cost } \\
\text { effective problem solving }\end{array}$ & 0.711 \\
\hline & Ability to translate knowledge into practice & 0.711 \\
\hline & Leadership, management and team work skills & 0.710 \\
\hline & $\begin{array}{l}\text { Ability to learn to learn and capacity for lifelong } \\
\text { learning }\end{array}$ & 0.692 \\
\hline & $\begin{array}{l}\text { Ability for conceptual thinking, analysis and } \\
\text { synthesis }\end{array}$ & 0.666 \\
\hline & Environmental and economic consciousness & 0.660 \\
\hline & Capacity for critical evaluation and self awareness & 0.635 \\
\hline & Ability to work independently & 0.614 \\
\hline & $\begin{array}{l}\text { Professionalism, ethical values and commitment } \\
\text { to UBUNTU (respect for the well being and dignity } \\
\text { of fellow human beings) }\end{array}$ & 0.612 \\
\hline & $\begin{array}{l}\text { Ability to communicate effectively in official/ } \\
\text { national and local language }\end{array}$ & 0.576 \\
\hline
\end{tabular}


In the case of Africa, graduates seem to give the same relevance to all competences, so no grouping has been extracted and all variables are in the same factor. Could it be concluded that there is a more holistic view, a more integrated or a less structured perspective of educational needs? This remains an open question.

Comparatively, in relation to the three categories, one could say that in the case of Europe and Latin America there are factors "dominated" by instrumental competences (factor 1 in both cases) while in Russia factors are more closely linked to systemic competences.

\section{Some conclusions}

The level of reflection and development of competences in the definition and designing of degree profiles varies according to traditions and educational systems. A number of conclusions can be drawn, while significant questions remain open to be dealt with in future work.

1. There are $\mathbf{1 6}$ competences which are highlighted internationally. From the comparison we can interpret that there are 16 global competences seen to be necessary to define any university degree. Despite having different formulations, the essence of the 16 competences are listed in the agreements of hundreds of academics who worked with the Tuning project in the four regions.

2. In each region there are other competences, not in the 16, which have high importance and these differences are very relevant. The 16 global competences are part of a larger list in each region, where there are other competences, some are identified in more than one region whilst others do not and are exclusively linked to the local context. This exclusivity coexisting with globalisation reflects flexibility of the Tuning approach in each region.

3. It is also critical to take into consideration the entire list, the complete picture of combination of elements as they define the profiles for citizenship that is considered as desirable in every region. The data suggests that the academics were aware of the critical value of the selection of competences required by different types of societies and how the present context was perceived as well as the possible evolution into the future.

4. The relevance of the context is critical, and is also the result of major global trends. The education systems of different countries refer to 
various combinations of competences. Such diversity may be valuable; however, if such generic competences are central elements of what defines a "graduate" it poses a challenge in terms of transfer between different higher education systems. On the other hand, there are clearly differences in the expectations and conceptions of generic competences which reflect cultural values and concepts. It would be culturally homogenizing to expect that the generic competences of a graduate valued in one region would be the same as those valued in other societies. The importance of context within which the generic competences are to be applied is critical. Each list of generic competences is abstracted from a context in which they have meaning. When generic competences are described without context, their meaning not anchored, and they imply learning without context.

5. The consultation with social groups is relevant to contrast the expectations of society in terms of the competences to be developed at university level. A joint reflection from the universities based on updated data is important in the development of adequate degrees. This demands not only a reflection on what local social and professional groups value and demand from their programmes but also the perspective of broader trends taking place at global level.

6. The results of the consultation show that despite being identified as common competences in all regions, and having a high level of validation as important characteristics of graduates (the ranking in terms of importance of competences has a range from 3.68 to 2.85 taking the four regions), the perception of graduates about what is considered important varies from region to region. Only 2 competences were identified as common among the 6 considered most important in the four regions. Likewise, at the other end of the importance scale, coincidences of graduates in Europe, Africa, Latin America and Russia were in just 2 competences. The rest of the analysed competences vary in order of importance across the regions, showing again the context of its constitution. It is significant that when the gaps between importance and achievement are analysed, coincidences increase in terms of which require further attention. These aspects between the important and the achievable enable regions to open a number of questions on how to teach and assess certain competences.

7. The factor analysis emphasizes more clearly the importance of regional contexts for the clustering of competences. There are not many similarities in ways of grouping competences. Taking as 
reference the Tuning classification of instrumental, interpersonal and systemic, in the four regions the response of graduates showed different ways of grouping. The analysis suggested that African graduates conceive the 16 competences in the same way, and the result is a single factor that integrates the whole. At the other extreme Russian graduates conceive the 16 competences as 4 factors. Although the study compares the 16 common competences, the factors are not comparable by region. This conclusion is very important because we may think that in order to be globally comparable we must include in the degree profiles those 16 competences. However, the phrasing and linkage to each other results in an unique combination totally related to the regional context.

8. Global competences are articulated with a contextual logic. The 16 common generic competences are global because of their coincidence in the four regions, but they have a way of being perceived and then organized in factors that responds to regional logic. This combination of global and local in generic competences is part of the Tuning project proposal, to work on common issues but respecting diversity. This example of 16 competences confirms this postulate of the common and the diverse coexisting at the core of the competences.

\section{Bibliography}

Agudín, Yolanda. "La Educación Superior Para Le Siglo XXI." Didac 36 (2000): 16-25.

Awono Onana, Charles, Olusola Bandele Oyewole, Damtew Teferra, Pablo Beneitone, Julia González, and Robert Wagenaar. Tuning and Harmonisation of Higher Education: The African Experience. Bilbao: University of Deusto, 2014. Beneitone, Pablo, César Esquetini, Julia González, Maida Marty Maleta, Gabriela

Siufi, and Robert Wagenaar. Reflections on and Outlook for Higher Education in Latin America. Bilbao: University of Deusto, 2007.

Boon, Jo and Marcel Van der Klink. "Competencies: The Triumph of a Fuzzy Concept." 27 February - 3 March, 2002.

Bowman, Kaye. Background Paper for the AQF Council on Generic Skills. Australian

Qualifications Framework Council, 2010.

Boyatzis, Richard E. The Competent Manager: A Model for Effective Performance. New York: John Wiley \& Sons, 1982.

Boyatzis, Richard E., Daniel Goleman, and Kenneth Rhee. "Clustering Competence in Emotional Intelligence Insights for the Emotional Competence Inventory." In Handbook of Emotional Intelligence. San Francisco: Jossey-Bass, 2000. 
Bryk, Anthony S., and Stephen W. Raudenbusch. Hierarchical Linear Models: Applications and Data Analysis Methods. Newbury Park, CA: Sage, 1992.

Chyung, Seung Youn, Donald Stepich, and David Cox. "Building a CompetencyBased Curriculum Architecture to Educate 21 st-Century Business Practitioners." Journal of Education for Business (2006): 307-314.

Cseh, Maria. "Facilitating Learning in Multicultural Teams." Advances in Developing Human Resources 5, no. 1 (2003): 26-40.

Demchuk, Artur, Ivan Dyukarev, Evgeniya Karavaeva, Pablo Beneitone, Julia González, and Robert Wagenaar. Towards Comparability of Higher Education Programmes. Information Review. Bilbao: University of Deusto, 2013.

Dooley, Kim E., James R. Lindner, Larry M. Dooley, and Meera Alagaraja. "Behaviorally Anchored Competencies: Evaluation Tool for Training Via Distance." Human Resource Development International 7, no. 3 (2004): 315-332. Draganidis, Fotis, Paraskevi Champoulou, and Gregoris Mentzas. «A Semantic Web Architecture for Integrating Competence Management and Learning Paths.» Journal of Knowledge Management 12, no. 6 (2008): 121-136.

Elleström, P-E. "The Many Meanings of Occupational Competence and Qualification." Journal of European Industrial Training 21, no. 6-7 (1997): 266-273.

European Commission. Explaining the European Qualifications Framework for Lifelong Learning. EC, 2008. http://ec.europa.eu/eqf/documentation_en.htm.

González, Julia, and Robert Wagenaar. Tuning Educational Structures in Europe: Final Report. Phase One. Bilbao: University of Deusto and University of Groningen, 2003.

Hofstede, Geert, Gert Jan Hofstede, and Michael Minkov.Cultures and Organizations: Software of the Mind. 3rd ed. New York: McGraw-Hill, 2010.

Jae On, Kim. Introduction to Factor Analysis: What it is and how to do it. California: Sage, 1978.

Kemp, Ian J. and Liz Seagraves. "Transferable Skills--can Higher Education Deliver?" Studies in Higher Education 20, no. 3 (1995): 315-329.

Marelli, Anne, Janis Tondora, and Michael Hoge. "Strategies for Developing Competency Model." Administration and Policy in Mental Health 32, no. 5-6 (2005): 533-561.

Melton, Reginald. Objectives, Competences and Learning Outcomes: Developing Instructional Materials in Open and Distance Learning. London: Kogan Page \& Institute of Educational Technology, Open University, 1997.

Mühlbacher, Jürgen, Michaela Nettekoven, and Anna Putnová. "Competence Development in the Czech Republic." Journal of Global Business and Technology 5, no. 2 (2009).

Prieto, José María. Prólogo to Gestión De Las Competencias, edited by Claude LevyLeboyer. Barcelona: Gestion 2000, 2002.

Robotham, David, and Richard Jubb. "Competences: Measuring the Unmeasurable." Management Development Review 9, no. 5 (1996): 25-29.

Rummel, Rudolph J. Applied Factor Analysis. Evanston: Northwestern University Press, 1970. 
Rychen, Dominique Simone, and Laura Hersh Salganik. Key Competences for a Successful Life and a Well-Functioning Society Hogrefe Publishing, 2003.

Spencer, Lyle M., David C. McClelland, and S. M. Spencer. Competency Assesment Methods. History and State of the Art. Boston: Hay-McBer Research Press, 1994.

Thomas, Edward. "Increasing Lifelong Learning in European Higher Education: The Challenges and the Prospects."24-25 February, 2000.

Villa, Aurelio. Marco Pedagógico De La Universidad De Deusto. Bilbao: University of Deusto, 2010.

Vittala, R. "Perceived Developmental Needs of Managers Compared to an Integrated Management Competency Model." Journal of Workplace Learning 17, no. 1 (2005): 436-451.

Williams, Peter. QAA. Council of Universties. Transparency for European Higher Education. Madrid: 2002.

Woodruffe, Charles. "What is Meant by Competency?" Leadership and Organizational Development Journal 14, no. 1 (1993): 29-36. 